\title{
IMPLEMENTASI GOOGLE SPEECH API PADA APLIKASI KOREKSI HAFALAN AL-QUR'AN BERBASIS ANDROID
}

\author{
(The Implementation of the Google Speech on Qur'an Recitation Correction \\ Application Based on Android)
}

\author{
Affandy Akbar, Ario Yudo Husodo*, Ariyan Zubaidi \\ Program Studi Teknik Informatika, Fakultas Teknik, Universitas Mataram \\ JI. Majapahit 62, Mataram, Lombok NTB, INDONESIA \\ Email: affanalafasy@gmail.com,ario@ti.ftunram.ac.id, zubaidi13@unram.ac.id
}

\begin{abstract}
Muroja'ah is a method of repeating new memorization and old memorization that be heard to other people. This method is very popular in Indonesia. In order to make the learning process isn't boring, it is required a learning media that can be used anytime, one of them are using Android application. The research describes how to build a Qur'an recitation correction application based on Android and integrate it with Google Speech so that application built more interesting and interactive with users. Google Speech be integrate as voice input media, users requested recite Qur'an verses then Google Speech will convert their voice to text. Text result obtained then matched with text in source code. Result of testing the accuracy of Google Speech implementation on this application it's 100\%, that means it's been as expected.
\end{abstract}

Keywords: Muroja'ah, Google Speech, Android, Qur'an, Voice Recognition

*Penulis korespondensi

\section{PENDAHULUAN}

Muroja'ah adalah metode mengulang hafalan, baik hafalan baru maupun hafalan lama yang disetorkan kepada orang lain. Dalam hal ini seorang hafidz Al-Qur'an dapat memperdengarkan hafalannya kepada guru ataupun orang lain. Metode ini sangat membantu, sebab terkadang jika mengulang sendiri hafalan Al-Qur'an terdapat kesalahan yang tidak disadari, akan berbeda jika melibatkan guru atau orang lain karena kesalahan-kesalahan yang terjadi akan mudah diketahui.

Cara yang biasa dilakukan oleh para hafidz AlQur'an untuk melakukan muroja'ah dengan mencari orang lain tergolong tidak fleksibel karena seorang hafidz Al-Qur'an harus mencari orang lain terlebih dahulu untuk menyetorkan hafalan mereka. Pada tahun 2016, Indonesia memiliki jumlah penghafal AlQur'an terbesar di dunia, tercatat penghafal Al-Qur'an di Indonesia pada tahun 2016 sekitar 35.000 orang, sedangkan di Arab Saudi hanya berjumlah 6.000 orang [1]. Oleh karena itu, para hafidz Al-Qur'an sangat membutuhkan suatu alat atau aplikasi yang dapat mengoreksi hafalan mereka tanpa harus bersusah payah mencari orang lain.

Pemanfaatan kemampuan smartphone untuk keperluan dibeberapa bidang pun dikembangkan dengan aplikasi-aplikasi yang mampu mendukung dalam penggunaannya. Termasuk diantara penggunaan smartphone dalam bidang agama adalah untuk media pembelajaran. Pengguna smartphone di Indonesia berkembang dengan cepat. Jumlah penduduk di Indonesia mencapai 250 juta jiwa. Lembaga riset digital marketing Emarketer memperkirakan pada tahun 2018 jumlah pengguna aktif smartphone di Indonesia lebih dari 100 juta orang. Dengan jumlah sebesar itu, Indonesia akan menjadi negara pengguna aktif smartphone terbesar keempat di dunia setelah Cina, India, dan Amerika[5].

Aplikasi mobile memiliki beragam sistem operasi Android, los, Microsoft, Symbian dan lainnya. Pengguna aplikasi mobile lebih banyak menggunakan sistem operasi Android, seperti dilansir badan statistik dunia bahwa persentase pengguna sistem operasi Android pada tahun 2017 adalah 88,37\% [2].

Pada penelitian ini, dibangun sebuah aplikasi koreksi hafalan Al-Qur'an berbasis android dengan mengimplementasikan Google Speech API sebagai media input suara. Sehingga aplikasi ini nantinya dapat digunakan oleh para hafidz Al-Qur'an sebagai media untuk melakukan muroja'ah kapan saja dan dimana saja.

Batasan masalah dalam pengerjaan penelitian ini adalah : 
1. Aplikasi ini memanfaatkan Google Speech API sebagai media input suara.

2. Aplikasi ini akan mengoreksi hafalan Al-Qur'an kemudian memberikan notifikasi jika hafalan benar ataupun salah.

3. Aplikasi ini terdiri dari 3 surah, yakni surah AlIkhlas, surah Al-Kautsar dan surah An-Naas.

4. Aplikasi harus terkoneksi dengan jaringan internet.

5. Aplikasi akan bekerja dengan maksimal jika jaringan internet baik.

6. Aplikasi ini dibatasi hanya untuk pengguna android saja.

\section{TINJAUAN PUSTAKA}

Pada penelitian yang dilakukan oleh Fauzan, peneliti menjelaskan bagaimana membangun aplikasi media pembelajaran iqro berbasis Android dan mengintegrasikannya dengan Google Speech menggunakan metode Speech Recognition (pengenalan suara)[3].

Pada penelitian yang dilakukan oleh Sutrisno, peneliti membuat automatic speech recognition pengenalan nama hewan berbasis Android. Dari uji coba yang dilakukan, aplikasi tersebut membantu orang tua dalam mengajarkan anak tentang nama hewan di sekitarnya[10].

Pada penelitian yang dilakukan oleh Saputra, peneliti memanfaatkan cloud Speech API untuk pengembangan media pembelajaran bahasa inggris menggunakan teknologi speech recognition. Dalam uji coba yang dilakukan peneliti berhasil merancang, membuat, dan mengimplementasikan aplikasi dengan memanfaatkan cloud Speech API untuk pembelajaran bahasa inggris[8].

Pada penelitian yang dilakukan oleh Susilo, peneliti menerapkan speech recognition pada permainan teka-teki silang menggunakan metode Hidden Markov Model (HMM) berbasis dekstop[11]. Penelitian ini memerlukan tempat pelatihan dan pengenalan suara yang jauh dari gangguan.

Pada penelitian yang dilakukan oleh Suryadharma, peneliti merancang aplikasi Speech to text bahasa inggris ke bahasa Bali berbasis Android. Aplikasi ini menerapkan Speech recognition dan tidak memerlukan akses internet sehingga dapat digunakan dimana saja bagi para wisatawan yang berniat mengetahui sedikit kata dalam bahasa Bali[13].

Pada penelitian yang dilakukan oleh Hariyani, dibuat suatu sistem yang mengendalikan lampu dari jarak jauh berbasis suara yang didukung oleh Google voice recognition dan menggunakan Android. Sistem ini dapat mematikan dan menghidupkan lampu, selain itu dapat juga mengatur lampu dengan beberapa tingkat intensitas cahaya. Peneliti ini menggunakan Arduino Uno R3 sebagai piranti pengendali dengan bluetooth sebagai media komunikasi antara smartphone dan mikrokontroller. Berdasarkan pengujian sistem dan alat yang dibuat, untuk pengujian di dalam ruangan dengan penghalang, jangkauan maksimal kontrol mencapai 10 meter dengan respon lampu rata-rata 1, 426 detik[4].

Pada penelitian yang dilakukan oleh Supriyanta, peneliti membangun aplikasi yang mengkonversi suara ke dalam teks dengan bahasa Indonesia. Aplikasi ini dibuat menggunakan Google Speech API. Aplikasi ini dapat mengurangi kesalahan inputan pada bidang teks. Selain itu aplikasi ini bisa digunakan untuk merekam pembicaraan yang hasil rekamannya sudah langsung berbentuk teks[12].

Pada penelitian yang dilakukan oleh Latief, peneliti berhasil membuat aplikasi voice command sebagai penghubung untuk mengendalikan perangkat elektronik rumah tangga. Hanya saja pada aplikasi ini belum ada fitur untuk menambah perangkat yang bisa dikendalikan oleh sistem pengendali dan belum ada fitur untuk menambahkan perintah suara[6].

Pada penelitian yang dilakukan oleh Shinwani, dirancang dan dibangun aplikasi voice translator berbasis Android menggunakan Hidden Markov Model. Aplikasi voice translator ini memanfaatkan suara sebagai inputan yang akan diproses sehingga pengguna tidak perlu mengetikkan kata yang akan dikirimkan. Aplikasi voice translator juga akan menerjemahkan hasil konversi suara ke teks ke dalam bahasa Inggris sehingga pengguna yang kurang bisa berbahasa Inggris dapat memanfaatkan aplikasi ini[9].

Pada penelitian yang dilakukan oleh Nurhidayat, dilakukan optimalisasi sistem pengenalan wicara dengan Levesthein Edit Distance untuk trading forex online. Pada penelitian ini, digunakan socket untuk komunikasi dengan software metatrader 4 dan HTTP Request/Response untuk komunikasi dengan Google Speech engine. Dari uji coba yang telah dilakukan, pengenalan suara menggunakan Google Speech API memberikan hasil yang lebih cepat dan tentunya kemudahan dibandingkan dengan pengoperasian manual. Hanya saja sistem aplikasi pengenalan suara pada penelitian ini menggunakan aplikasi yang berbeda platform dengan software metatrader sehingga memerlukan socket untuk dapat berkomunikasi dan terdapat jeda waktu ketika mengirimkan perintah transaksi[7]. 


\subsection{Dasar Teori}

\subsubsection{Sistem Pakar}

Google Speech API diperkenalkan pada tahun 2008 di Amerika Serikat untuk beberapa tipe smartphone. Google Speech API adalah sebuah kerangka kerja yang dibuat oleh Google untuk mengenali suara, dirubah menjadi string (teks) dan dimasukkan ke dalam halaman pencarian Google sehingga akan menampilkan hasil pencarian berdasarkan masukan suara tersebut. Pengenalan suara dilakukan pada server Google menggunakan algoritma Hidden Markov Model (HMM). Dengan kata lain input suara yang diterima oleh perangkat Android akan dikirimkan ke server Google, yang selanjutnya server Google melakukkan pengenalan dan mengubahnya menjadi teks menggunakan algoritma HMM. Hasil konversi berupa teks kemudian dimasukkan ke dalam halaman pencarian Google kemudian server Google akan mengirimkan hasil pencariannya tersebut ke perangkat Android.

Speech Recognition atau Google Speech adalah suatu API yang disediakan oleh Google untuk mengidentifikasi suara dengan menggunakan cara digitalisasi kata dan mencocokkan sinyal digital tersebut dengan suatu pola yang tersimpan di dalam database Google. Teknologi Speech Recognition merupakan teknologi pengenalan kata yang memanfaatkan sinyal suara manusia sebagai masukan untuk kemudian dikenali oleh sistem komputer. Teknologi ini merupakan pengembangan interaksi antara manusia dengan komputer untuk meminimalisir peralatan input device seperti mouse, keyboard maupun peralatan interface lainnya.

\subsubsection{Hubungan Pengenalan Suara dengan Al}

Kecerdasan buatan (Artifical Intelegent) merupakan cabang ilmu pengetahuan yang berhubungan dengan pemanfaatan mesin untuk memecahkan persoalan yang rumit. Pemahaman ucapan/suara (Speech/Voice Understanding) adalah teknik agar komputer dapat mengenali dan memahami bahasa ucapan. Proses ini mengizinkan seseorang berkomunikasi dengan komputer dengan cara berbicara kepadanya. Istilah pengenalan suara mengandung arti bahwa tujuan utamanya adalah mengenali kata yang diucapkan tanpa harus tahu artinya. Secara umum prosesnya adalah usaha untuk menerjemahkan apa yang diucapkan seorang manusia menjadi kata atau kalimat yang dapat dimengerti oleh komputer.

\subsection{Alat dan Bahan}

\section{METODE PENELITIAN}

Penelitian ini mengunakan alat dan bahan yang terdiri dari perangkat keras (hardware) dan perangkat lunak (software), sebagai berikut:

1. Laptop Asus K45A processor Intel Core i3 dengan clock frekuensi $2,40 \mathrm{GHz}$, Ram $6 \mathrm{~GB}$.

2. Sistem operasi Windows 10 Pro.

3. Smartphone Xiaomi Note 5A, RAM 2 GB.

4. Google Speech API sebagai framework pengenalan kata.

5. Android Studio sebagai editor.

\subsection{Metode Pengembangan Sistem}

Pengembangan sistem yang akan dibangun ini menggunakan model waterfall. Model waterfall digunakan dalam pengembangan sistem ini karena prosesnya mengalir secara sistematis dari satu tahap ke tahap yang lain sehingga mudah untuk digunakan dalam pengembangan suatu sistem.

Gambar 1 adalah diagram alur atau proses penggambaran pembuatan sistem.

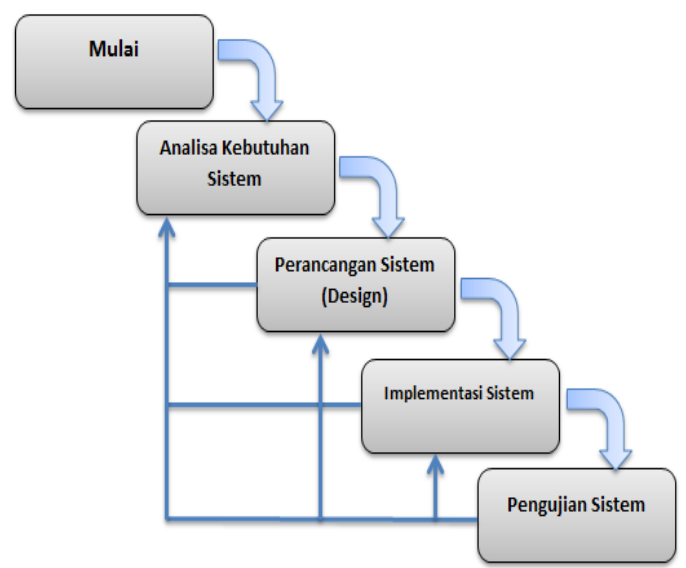

Gambar 1. Pengembang sistem model waterfall

\subsubsection{Analisis Kebutuhan Sistem}

Pada tahap ini dilakukan penjabaran kebutuhan fungsional pengguna aplikasi sehingga aplikasi dapat dirancang dengan baik dan dapat berjalan dengan optimal. Secara umum kebutuhan fungsional yang harus ada di dalam aplikasi koreksi hafalan Al-Qur'an dapat dilihat pada Tabel I.

TABEL I. DESKRIPSI KEBUTUHAN

\begin{tabular}{|l|l|}
\hline \multicolumn{1}{|c|}{ Nama Fungsi } & \multicolumn{1}{|c|}{ Deskripsi Kebutuhan } \\
\hline Mengoreksi Hafalan & $\begin{array}{l}\text { Aplikasi harus mengeluarkan notifikasi } \\
\text { berupa audio dan gambar jika bacaan } \\
\text { benar ataupun salah. }\end{array}$ \\
\hline Mengetahui Poin & $\begin{array}{l}\text { Aplikasi harus menghitung total poin yang } \\
\text { didapatkan oleh pengguna dari total } \\
\text { bacaan yang benar. }\end{array}$ \\
\hline & \\
\hline
\end{tabular}




\subsubsection{Perancangan Sistem}

Dalam tahap ini, terdapat lima tahap perancangan yang dilakukan, yaitu perancangan use case, class diagram, squence diagram, arsitektur sistem, perancangan tampilan aplikasi dan perancangan database.

\subsubsection{Perancangan use case diagram}

Use case diagram menggambarkan proses-proses yang dapat dilakukan dilakukan oleh aktor. Use case diagram aplikasi koreksi hafalan Al-Qur'an dapat dilihat pada Gambar 2.

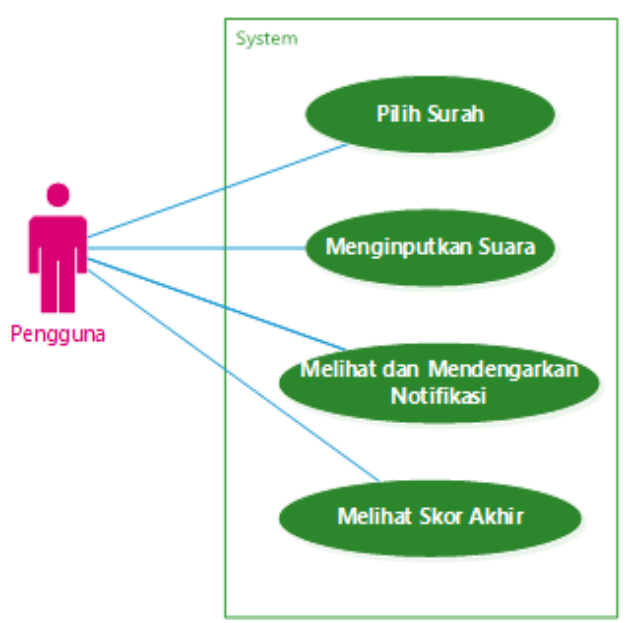

Gambar 2. Use Case Diagram

\subsubsection{Perancangan Sequence Diagram}

Sistem pertama kali akan menjalankan method onCreate(), Setelah itu pengguna akan memilih surat yang ingin dimuroja'ah. Pada surah yang telah dipilih, sistem menjalankan method getSpeechInput()kemudian pengguna melafadzkan ayat tertentu. Selanjutnya sistem menjalankan method onActivityResult() yang bertujuan untuk mengubah perintah suara menjadi teks lalu teks tersebut akan disesuaikan dengan kondisi yang telah dibuat sebelumnya kemudian sistem akan menampilkan notifikasi kepada pengguna. Gambaran dari squence diagram pada aplikasi koreksi hafalan AlQur'an dapat dilihat pada Gambar 3.

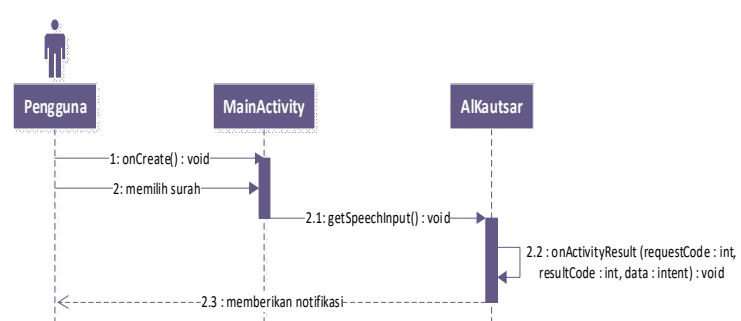

Gambar 3. Rancangan Squence diagram

\subsubsection{Arsitektur sistem dan alur kerja sistem}

Gambaran arsitektur dan alur kerja sistem dari aplikasi koreksi hafalan Al-Qur'an yang akan dibangun memiliki 5 alur kerja sistem. Pertama, pengguna melafadzkan ayat sesuai dengan surah yang dipilih. Kedua, sistem akan memperoses perintah tersebut melalui Google Speech. Ketiga, Google Speech mengubah perintah suara tersebut menjadi teks. Keempat, Sitem akan merequest string dari database. Kelima, String yang didapatkan dari database akan disesuaikan dengan string yang didapatkan dari Google. Keenam, pengguna mendapatkan notifikasi dari hasil bacaan yang dilafadzkan. Gambaran arsitektur dan alur kerja sistem dapat dilihat pada Gambar 4.

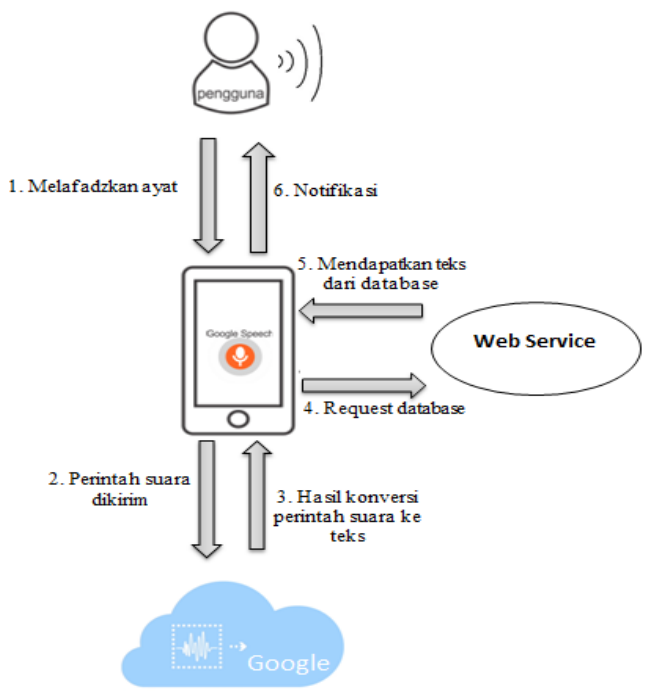

Gambar 4. Arsitektur dan alur kerja sistem

\subsubsection{Implementasi}

Setelah melakukan tahap perancangan maka akan dilakukan proses implementasi yaitu pembangunan Mobile Application. Pada tahap pembangunan mobile application, rancangan mobile application akan diimplementasikan ke dalam smartphone menggunakan bahasa pemrograman Java dan Android Studio sebagai alat bantu dalam proses implementasi.

\subsubsection{Pengujian Sistem}

Teknik pengujian yang digunakan untuk melakukan pengujian pada aplikasi koreksi hafalan AlQur'an yaitu black box yang berfungsi untuk mengetahui kinerja dari fitur-fitur yang ada pada sistem. Selanjutnya pengujian dilakukan dengan menggunakan tabel pengujian akurasi Google speech untuk masing-masing surah. Tabel pengujian akurasi Google speech dapat dilihat pad Gambar 5. 
TABEl II. Pengujian Aplikasi Pada Masing-Masing Surah

\begin{tabular}{|c|c|c|c|c|c|c|c|}
\hline \multirow{2}{*}{ Surah } & \multirow{2}{*}{ Ayat } & \multirow{2}{*}{$\begin{array}{l}\text { Potong } \\
\text { an Ayat }\end{array}$} & \multicolumn{5}{|c|}{ Penguji } \\
\hline & & & A & B & C & D & $E$ \\
\hline
\end{tabular}

Tabel pengujian (Tabel II) terdiri dari 4 kolom, yaitu :

1. Surah : Berisi nama surah

2. Ayat : Berisi ayat-ayat pada surah yang diuji

3. Potongan ayat : Berisi potongan ayat dalam bentuk kata

4. Penguji : Berisi hasil akurasi yang didapatkan dari masing-masing penguji

\subsection{Implementasi}

\section{HASIL DAN PEMBAHASAN}

Dalam penelitian ini, terdapat beberapa hal yang akan dibahas terkait implementasi rancangan aplikasi yang telah dijabarkan sebelumnya.

\subsubsection{Implementasi Kelas}

Implementasi kelas pada Aplikasi Koreksi Hafalan Al-Qur'an merupakan kelas yang berisi bahasa pemrograman yang dibuat untuk mengimplementasikan sistem sesuai dengan perancangan yang dilakukan berupa source code (coding). Implementasi kelas pada Aplikasi Koreksi Hafalan Al-Qur'an dapat dilihat pada Tabel III.

TABEL III. IMPLEMENTASI KELAS

\begin{tabular}{|l|l|}
\hline \multicolumn{1}{|c|}{$\begin{array}{c}\text { Nama file } \\
\text { Program }\end{array}$} & \multicolumn{1}{|c|}{ Keterangan } \\
\hline CSplashScreen & $\begin{array}{l}\text { Kelas yang dijalankan } \\
\text { pertama kali ketika aplikasi } \\
\text { dibuka. }\end{array}$ \\
\hline CMainActivity & $\begin{array}{l}\text { Kelas Utama yang dijalankan } \\
\text { pertama kali setelah kelas } \\
\text { CSplashScreen }\end{array}$ \\
\hline CAyat & $\begin{array}{l}\text { Kelas untuk melakukan } \\
\text { pengecekan string }\end{array}$ \\
\hline CBenar & $\begin{array}{l}\text { Kelas untuk menampilkan } \\
\text { notifikasi jika bacaan benar }\end{array}$ \\
\hline CSalah & $\begin{array}{l}\text { Kelas untuk menampilkan } \\
\text { notifikasi jika bacaan salah }\end{array}$ \\
\hline CSkor & $\begin{array}{l}\text { Kelas untuk menampilkan } \\
\text { skor akhir }\end{array}$ \\
\hline
\end{tabular}

Untuk dapat mengenali suara yang dimasukkan ke aplikasi, digunakan Google API yang akan menerjemahkan suara masukan menjadi string. Dari string ini, akan dicocokkan dengan string yang ada di database.

\subsubsection{Implementasi Interface Aplikasi}

Interface merupakan antar muka yang akan berinteraksi secara langsung dengan pengguna aplikasi. Dalam implementasi interface yang telah dikembangkan berdasarkan perancangan yang telah dibuat sebelumnya, tampilan aplikasi dibagi menjadi beberapa interface sebagai berikut :

\subsubsection{Interface halaman muroja'ah}

Pada halaman ini terdapat sebuah tombol yang berfungsi untuk memulai dan mengakhiri muroja'ah pada ayat tertentu. Implementasi Interface halaman muroja'ah dapat dilihat pada Gambar 5.
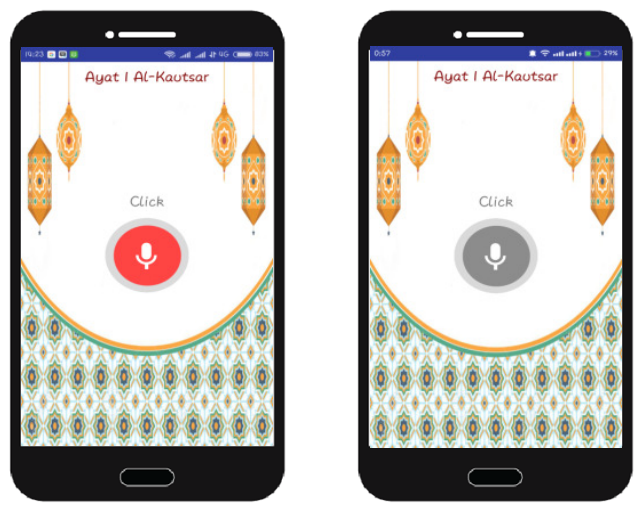

Gambar 5. Interface halaman muroja'ah

Dari halaman input suara, pengguna diminta menekan tombol 2 kali. Secara default tombol input suara memiliki warna merah, jka tombol ditekanan maka warna tombol akan berubah menjadi abu-abu kemudian sistem akan merekam suara yang diucapkan oleh pengguna. Setelah selesai mengucapkan/ melafadzkan ayat maka pengguna harus menekan kembali tombol input suara tersebut hingga warna tombol kembali ke dalam kondisi default (merah).

\subsubsection{Interface jika bacaan benar}

Pada halaman ini aplikasi akan menampilkan layout disertai dengan audio ketika bacaan yang telah dilafadzkan pada halaman muroja'ah bernilai benar, selanjutnya pengguna dapat melanjutkan muroja'ah ke ayat berikutnya dengan memilih tombol lanjut. Interface jika bacaan benar dapat dilihat pada Gambar 6. 


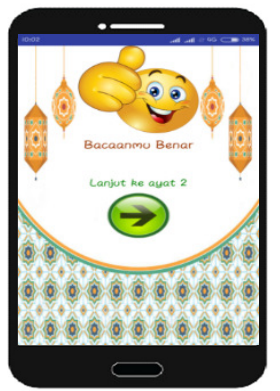

Gambar 6. Interface jika bacaan benar

\subsubsection{Interface jika bacaan salah}

Pada halaman ini, aplikasi akan menampilkan layout disertai audio koreksi bacaan ketika bacaan yang telah dilafadzkan pada halaman muroja'ah bernilai salah. Selanjutnya pengguna dapat mengulang kembali melafadzkan ayat dengan menekan tombol "ok". Parameter bacaan dikatakan salah adalah jika hasil konversi teks Google Speech tidak sesuai dengan teks pada source code. Interface halaman jika bacaan salah dapat dilihat pada Gambar 7.

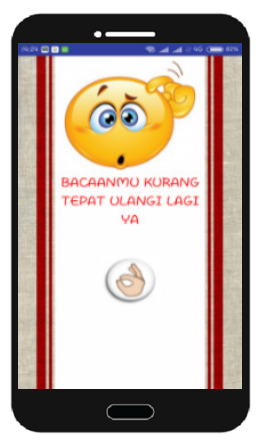

Gambar 7. Interface jika bacaan salah

\subsubsection{Interface hasil skor akhir hafalan}

Pada halaman ini, setelah pengguna telah selesai melakukan muroja'ah, maka sistem akan mengkalkulasikan skor akhir pengguna dari total bacaan yang benar pada setiap ayatnya. Interface halaman skor akhir hafalan dapat dilihat pada Gambar 8.

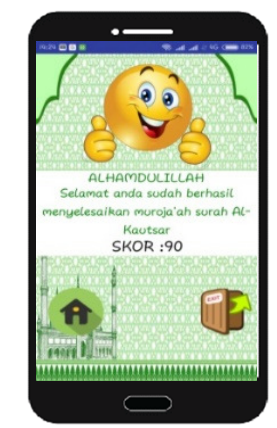

Gambar 8. Interface halaman skor akhir hafalan

\subsection{Pengujian}

Aplikasi yang telah menempuh tahap implementasi akan memasuki tahap pengujian untuk mengetahui sejauh mana keberhasilan aplikasi dan kualitasnya. Pengujian menggunakan metode black box dan tabel perhitngan akurasi.

\subsubsection{Hasil Pengujian Black Box}

Metode ini menguji fungsi-fungsi pada aplikasi koreksi hafalan Al-Qur'an untuk menentukan apakah fungsi-fungsi tersebut sudah berjalan sesuai harapan atau tidak. Pengujian black box dapat dilihat pada Tabel IV.

tabel IV. Hasil Pengujian Black Box

\begin{tabular}{|c|c|c|c|}
\hline Skenario pengujian & Hasil yang di harapkan & $\begin{array}{c}\text { Hasil } \\
\text { pengujian }\end{array}$ & Kesimpulan \\
\hline I & II & III & IV \\
\hline $\begin{array}{l}\text { Menekan tombol "clik" } \\
\text { pada halaman muroja"ah }\end{array}$ & $\begin{array}{l}\text { Sistem akan terhubung } \\
\text { dengan Google Speech }\end{array}$ & \begin{tabular}{|l} 
Sesuai \\
\end{tabular} & Valid \\
\hline $\begin{array}{l}\text { Melafadzkan } \quad \text { bacaan } \\
\text { dengan baik dan benar. }\end{array}$ & 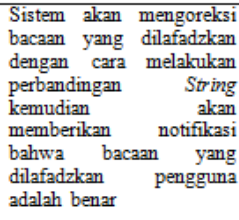 & Sesuai & Valid \\
\hline $\begin{array}{l}\text { Melafadzkan bacaan } \\
\text { dengan suara yang samar } \\
\text { dan bacaan yang salah }\end{array}$ & 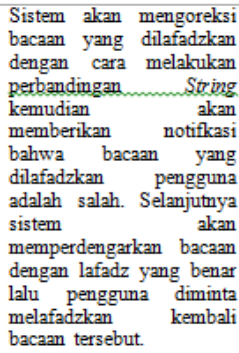 & Sesuai & Valid \\
\hline $\begin{array}{l}\text { Berhasil menyelesaikan } \\
\text { hafalan }\end{array}$ & $\begin{array}{l}\text { Sistem akan menampilkan } \\
\text { skor akhir pengguna }\end{array}$ & Sesuai & Valid \\
\hline
\end{tabular}

\subsubsection{Tabel Perhitungan pengujian aplikasi}

Pada proses pengujian ini, aplikasi akan diuji oleh 5 orang santri, 3 diantaranya yang sudah fasih dan baik dalam melafadzkan Al-Qur'an yaitu A, B, dan C. kemudian 2 diantaranya memiliki kemampuan bacaan yang standar (tidak fasih dan tidak pula terbata-bata) yaitu $D$ dan E. Pengujian dilakukan pada koneksi internet yang baik dan jauh dari gangguan. Tabel Pengujian Akurasi Google Speech dapat dilihat pada Tabel V, VI dan VII. 
TABEL V. Pengujian Aplikasi Pada Surah Al-IKHLAS

\begin{tabular}{|c|c|c|c|c|c|c|}
\hline \multirow[t]{2}{*}{ Ayat } & \multirow[t]{2}{*}{ Lafadz } & \multicolumn{5}{|c|}{ Penguji } \\
\hline & & $A$ & B & $\mathrm{C}$ & D & $E$ \\
\hline 1 & $\begin{array}{c}\text { Qul Huwallahu } \\
\text { Ahad }\end{array}$ & $\begin{array}{c}\text { Benar } \\
\text { (Sesuai) }\end{array}$ & $\begin{array}{c}\text { Benar } \\
\text { (Sesuai) }\end{array}$ & $\begin{array}{c}\text { Benar } \\
\text { (Sesuai) }\end{array}$ & $\begin{array}{c}\text { Benar } \\
\text { (Sesuai) }\end{array}$ & $\begin{array}{c}\text { Benar } \\
\text { (Sesuai) }\end{array}$ \\
\hline 2 & Allahu Samad & $\begin{array}{c}\text { Benar } \\
\text { (Sesuai) }\end{array}$ & $\begin{array}{c}\text { Benar } \\
\text { (Sesuai) }\end{array}$ & $\begin{array}{c}\text { Benar } \\
\text { (Sesuai) }\end{array}$ & $\begin{array}{c}\text { Benar } \\
\text { (Sesuai) }\end{array}$ & $\begin{array}{c}\text { Benar } \\
\text { (Sesuai) }\end{array}$ \\
\hline 3 & $\begin{array}{c}\text { Lam Yalid } \\
\text { Walam Yulad }\end{array}$ & $\begin{array}{c}\text { Benar } \\
\text { (Sesuai) }\end{array}$ & $\begin{array}{c}\text { Benar } \\
\text { (Sesuai) }\end{array}$ & $\begin{array}{c}\text { Benar } \\
\text { (Sesuai) }\end{array}$ & $\begin{array}{c}\text { Benar } \\
\text { (Sesuai) }\end{array}$ & $\begin{array}{l}\text { Benar } \\
\text { (Sesuai) }\end{array}$ \\
\hline 4 & $\begin{array}{c}\text { Walam } \\
\text { Yakullahu } \\
\text { Kufuwan Ahad }\end{array}$ & $\begin{array}{c}\text { Benar } \\
\text { (Sesuai) }\end{array}$ & $\begin{array}{c}\text { Benar } \\
\text { (Sesuai) }\end{array}$ & $\begin{array}{c}\text { Benar } \\
\text { (Sesuai) }\end{array}$ & $\begin{array}{c}\text { Salah } \\
\text { (Sesuai) }\end{array}$ & $\begin{array}{c}\text { Salah } \\
\text { (Sesuai) }\end{array}$ \\
\hline & Akurasi (\%) & $100 \%$ & $100 \%$ & $100 \%$ & $100 \%$ & $100 \%$ \\
\hline \multicolumn{2}{|c|}{ Rata-Rata Akurasi(\%) } & \multicolumn{5}{|c|}{$100 \%$} \\
\hline
\end{tabular}

Berikut ini merupakan rumus untuk menentukan rata-rata akurasi dari pengujian yang telah dilakukan untuk Surat Al Ikhlas.

$$
\text { Rata }- \text { rata akurasi }=\frac{(100)+(100)+(100)+(100)+(100)}{5}=100 \%
$$

TABEL VI. Pengujian Aplikasi Pada Surah Al-Kautsar

\begin{tabular}{|c|c|c|c|c|c|c|}
\hline \multirow[t]{2}{*}{ Ayat } & \multirow[t]{2}{*}{ Lafadz } & \multicolumn{5}{|c|}{ Penguji } \\
\hline & & A & B & $\mathrm{C}$ & D & $\mathrm{E}$ \\
\hline 1 & $\begin{array}{l}\text { Inna a'thoina } \\
\text { Kal Kautsar }\end{array}$ & $\begin{array}{c}\text { Benar } \\
\text { (Sesuai) }\end{array}$ & $\begin{array}{l}\text { Benar } \\
\text { (Sesuai) }\end{array}$ & $\begin{array}{c}\text { Benar } \\
\text { (Sesuai) }\end{array}$ & $\begin{array}{c}\text { Benar } \\
\text { (Sesuai) }\end{array}$ & $\begin{array}{c}\text { Benar } \\
\text { (Sesuai) }\end{array}$ \\
\hline 2 & $\begin{array}{c}\text { Fasholli } \\
\text { Lirobbika } \\
\text { Wanhar }\end{array}$ & $\begin{array}{c}\text { Benar } \\
\text { (Sesuai) }\end{array}$ & $\begin{array}{l}\text { Benar } \\
\text { (Sesuai) }\end{array}$ & $\begin{array}{c}\text { Benar } \\
\text { (Sesuai) }\end{array}$ & $\begin{array}{c}\text { Benar } \\
\text { (Sesuai) }\end{array}$ & $\begin{array}{l}\text { Benar } \\
\text { (Sesuai) }\end{array}$ \\
\hline 3 & $\begin{array}{c}\text { Innasya Niaka } \\
\text { Huwal Abtar }\end{array}$ & $\begin{array}{c}\text { Benar } \\
\text { (Sesuai) }\end{array}$ & $\begin{array}{l}\text { Benar } \\
\text { (Sesuai) }\end{array}$ & $\begin{array}{c}\text { Benar } \\
\text { (Sesuai) }\end{array}$ & $\begin{array}{c}\text { Benar } \\
\text { (Sesuai) }\end{array}$ & $\begin{array}{l}\text { Benar } \\
\text { (Sesuai) }\end{array}$ \\
\hline & Akurasi (\%) & $100 \%$ & $100 \%$ & $100 \%$ & $100 \%$ & $100 \%$ \\
\hline \multicolumn{2}{|c|}{ Rata-Rata Akurasi(\%) } & \multicolumn{5}{|c|}{$100 \%$} \\
\hline
\end{tabular}

Ini merupakan rumus yang digunakan untuk menghitung rata-rata akurasi aplikasi untuk Surat AlKautsar.

Rata - rata akurasi $=\frac{(100)+(100)+(100)+(100)+(100)}{5}=100 \%$
TABEL VII. Pengujian Aplikasi Speech Pada Surah An-NaAs

\begin{tabular}{|c|c|c|c|c|c|c|}
\hline \multirow[t]{2}{*}{ Ayat } & \multirow[t]{2}{*}{ Lafadz } & \multicolumn{5}{|c|}{ Penguji } \\
\hline & & A & B & C & D & E \\
\hline \multirow[t]{4}{*}{1} & $\begin{array}{l}\text { Qul A'udzu } \\
\text { Birabbinnas }\end{array}$ & $\begin{array}{l}\text { Benar } \\
\text { (Sesuai) }\end{array}$ & $\begin{array}{c}\text { Benar } \\
\text { (Sesuai) }\end{array}$ & $\begin{array}{c}\text { Benar } \\
\text { (Sesuai) }\end{array}$ & $\begin{array}{c}\text { Benar } \\
\text { (Sesuai) }\end{array}$ & $\begin{array}{c}\text { Benar } \\
\text { (Sesuai) }\end{array}$ \\
\hline & Malikinnas & $\begin{array}{l}\text { Benar } \\
\text { (Sesuai) }\end{array}$ & $\begin{array}{c}\text { Benar } \\
\text { (Sesuai) }\end{array}$ & $\begin{array}{c}\text { Benar } \\
\text { (Sesuai) }\end{array}$ & $\begin{array}{c}\text { Benar } \\
\text { (Sesuai) }\end{array}$ & $\begin{array}{c}\text { Benar } \\
\text { (Sesuai) }\end{array}$ \\
\hline & Ilahinnas & $\begin{array}{c}\text { Benar } \\
\text { (Sesuai) }\end{array}$ & $\begin{array}{c}\text { Benar } \\
\text { (Sesuai) }\end{array}$ & $\begin{array}{c}\text { Benar } \\
\text { (Sesuai) }\end{array}$ & $\begin{array}{c}\text { Benar } \\
\text { (Sesuai) }\end{array}$ & $\begin{array}{c}\text { Benar } \\
\text { (Sesuai) }\end{array}$ \\
\hline & $\begin{array}{l}\text { Min Syarril was } \\
\text { waasil Khannas }\end{array}$ & $\begin{array}{c}\text { Benar } \\
\text { (Sesuai) }\end{array}$ & $\begin{array}{c}\text { Benar } \\
\text { (Sesuai) }\end{array}$ & $\begin{array}{c}\text { Benar } \\
\text { (Sesuai) }\end{array}$ & $\begin{array}{l}\text { Salah } \\
\text { (Sesuai) }\end{array}$ & $\begin{array}{l}\text { Salah } \\
\text { (Sesuai) }\end{array}$ \\
\hline 5 & $\begin{array}{c}\text { Alladzi } \\
\text { yuwaswisu fii } \\
\text { Sudurinnas }\end{array}$ & $\begin{array}{c}\text { Benar } \\
\text { (Sesuai) }\end{array}$ & $\begin{array}{c}\text { Benar } \\
\text { (Sesuai) }\end{array}$ & $\begin{array}{c}\text { Benar } \\
\text { (Sesuai) }\end{array}$ & $\begin{array}{c}\text { Salah } \\
\text { (Sesuai) }\end{array}$ & $\begin{array}{c}\text { Salah } \\
\text { (Sesuai) }\end{array}$ \\
\hline 6 & $\begin{array}{c}\text { Minal Jinnati } \\
\text { Wannas }\end{array}$ & $\begin{array}{c}\text { Benar } \\
\text { (Sesuai) }\end{array}$ & $\begin{array}{c}\text { Benar } \\
\text { (Sesuai) }\end{array}$ & $\begin{array}{c}\text { Benar } \\
\text { (Sesuai) }\end{array}$ & $\begin{array}{c}\text { Benar } \\
\text { (Sesuai) }\end{array}$ & $\begin{array}{c}\text { Benar } \\
\text { (Sesuai) }\end{array}$ \\
\hline & Akurasi (\%) & $100 \%$ & $100 \%$ & $100 \%$ & $100 \%$ & $100 \%$ \\
\hline Rata- & 4 & & & $100 \%$ & & \\
\hline
\end{tabular}

Rata - rata akurasi $=\frac{(100)+(100)+(100)+(100)+(100)}{5}=100 \%$

Rata - rata akurasi keseluruhan $=\frac{(1.6)+(2.6)+(3.6)}{\text { total data }} \times 100 \%$

Rata - rata akurasi keseluruhan $=\frac{(100)+(100)+(100)}{3} \times 100 \%=100 \%$

Jadi rata-rata akurasi aplikasi ini dengan kasus surah Al-Ikhlas, Al-Kautsar dan An-Naas adalah 100\%, artinya sudah sesuai dengan harapan.

\subsection{Kesimpulan}

\section{KESIMPULAN DAN SARAN}

Berdasarkan pembangunan aplikasi dan implementasi Google Speech API yang telah dilakukan pada Aplikasi Koreksi Hafalan Al-Qur'an maka dapat disimpulkan bahwa:

1. Pembuatan aplikasi ini sudah memenuhi kebutuhan pengguna sesuai dengan yang dijabarkan pada kebutuhan sistem.

2. Aplikasi Koreksi Hafalan Al-Qur'an dapat mengolah inputan suara dengan mengimplementasikan Google Speech API.

3. Dari Hasil pengujian black box menunjukkan bahwa seluruh fungsi telah berjalan sesuai dengan aplikasi yang diharapkan.

4. Google Speech API tidak bisa mendeteksi dengan maksimal lafadz ayat yang cenderung lebih panjang dan melafadzkan dengan suara yang kurang jelas.

5. Rata-rata akurasi Google speech API dalam mengkonversi inputan suara menjadi teks pada 
studi kasus surah Al-Ikhlas, Al-Kautsar dan AnNaas adalah $100 \%$.

\subsection{Saran}

Terdapat beberapa saran yang perlu disampaikan berdasarkan hasil pembahasan pada penelitian ini yaitu :

1. Aplikasi masih memanfaatkan Google Speech sebagai media input suara, maka untuk penelitian selanjutnya dapat menciptakan inputan suara yang lain tanpa harus menggunakan Google Speech

2. Aplikasi masih bersifat online, maka diharapkan peneliti selanjutnya mampu mengembangkan Aplikasi Koreksi Hafalan Al-Qur'an versi offline.

3. Diharapkan dapat meningkatkan fitur pengkoreksian menjadi lebih detail yang meliputi pengkoreksian hukum tajwid.

4. Diharapkan dapat menambah surah Al-Qur'an menjadi lebih banyak lagi.

\section{Daftar Pustaka}

[1] Anonim, Jumlah Penghafal Al-Qur'an Di Indonesia, https://quranpedia.id/blog/jumlah-penghafal-quran-diindonesia-terbesar-di-dunia.html, diakses pada 20 Maret 201812.03 PM.

[2] Anonim, Smartphone, https://www.statista.com/topics/840/smartphones.html diakses pada 20 Maret 201810.07 AM.

[3] Fauzan, A. 2018, Pembangunan Aplikasi Iqro' Berbasis Android Menggunakan Google Speech, Teknik Informatika, Universitas Brawijaya, Vol. 2, No.1, Januari 2018, hlm.29-35.

[4] Hariyani. 2014, Realisasi Pengendali Intensitas Cahaya Lampu Dengan Kontrol Suara dan Google Android Speech Recognition API, Teknik Telekomunikasi, Universitas Telkom Bandung.

[5] Kominfo. https://kominfo.go.id/index/jumlah pengguna smarphone meningkat.php diakses pada 20 Maret 2018 10.30 AM.

[6] Latief. 2015, Voice Command Pengendali Perangkat Elektronik Rumah Tangga Menggunakan Raspberry PI, UIN Sunan Kalijaga Yogyakarta.

[7] Nurhidayat. 2014, “Optimalisasi Sistem Pengenalan Wicara dengna Levesthein Edit Distance Untuk Trading Forex Online". Teknik Telekomunikasi Universitas Telkom Bandung.

[8] Saputra, S. 2017, Pemanfaatan Cloud Speech API Untuk Pengembangan Media Pembelajaran Bahasa Inggris Menggunakan Teknologi Speech Recognition, Teknik Informatika, STMIK Amikom Purwokerto.
[9] Shinwani. 2016, "Rancang Bangun Aplikasi Voice Translator Berbasis Android Menggunakan Hidden Markov Model", Teknik Informatika Universitas Negeri Maulana Malik Ibrahim Malang.

[10] Sutrisno, J. 2016, Aplikasi Pengenalan Nama Hewan Dengan Metode Speech Recognition Berbasis Android, Teknik Informatika, Universitas Muhammadiyah Sidoarjo.

[11] Susilo, B. 2016, Penerapan Speech Recognition Pada Permainan Teka-Teki Silang Berbasis Desktop, Teknik Informatika, Universitas Bengkulu, Vol. 4, No.1 Maret 2016.

[12] Supriyanta. 2014, Aplikasi Konversi Suara Ke Teks Berbasis Android Menggunakan Google Speech API, AMIK BSI Yogyakarta, Vol. 2, No. 2 September 2014.

[13] Suryadharma. 2014, Perancangan Aplikasi Speech To Text Bahasa Inggris Ke Bahasa Bali Menggunakan Pocketsphinx Berbasis Android, Teknik Telekomunikasi, Universitas Telkom Bandung. 